\title{
LETTER
}

\section{Surface Active Properties of New Types of Amphipathic Compounds with Two Hydrophilic Ionic Groups and Two Lipophilic Alkyl Chains}

\author{
Mitsuo Orahara, Araki Masuyama, Yasushi Sumida, and Yun-Peng Zhu \\ Department of Applied Chemistry, Faculty of Engineering, Osaka University \\ (2-1, Yamadaoka, Suita-shi, T565)
}

Disodium 1,8-bis (alkyloxymethyl)-3,6-dioxaoctane-1,8-disulfates and disodium 5, 12-bis (alkyloxymethyl)4, 7, 10, 13-tetraoxahexadecane-1,16-disulfonates (alkyl; octyl or decyl) were prepared from 1,8-bis (alkyloxymethyl)-3,6-dioxaoctane-1,8-diols obtained by reactions of ethylene glycol diglycidyl ether with octyl or decyl alcohol. These new types of compounds showed excellent surface active properties in water.

Amphipathic compounds with plural lipophilic alkyl groups have been widely studied on their applications to the artificial bilayer membrane

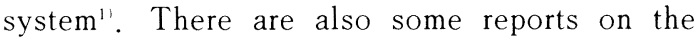
surface active properties of compounds containing plural lipophilic alkyl groups ${ }^{2}$ or plural hydrophilic functional groups ${ }^{33}$.

Recently, we have developed the facile synthetic method of oligo (ethylene glycol) diglycidyl ethers ${ }^{41}$ and studied on the preparation and properties of many functional products from them ${ }^{5 / \infty 1}$.

In this report we describe the syntheses and the interesting surface active properties of new types of amphipathic compounds $(2,3)$ which are derived from ethylene glycol diglycidyl ether (EGDG) and have two hydrophilic ionic groups and two lipophilic alkyl chains.

Synthetic routes to 2 and 3 are shown in Fig.-1. Diols $(1 \mathrm{a}, \mathrm{b})$ were prepared and isolated (ca. $50 \%$ yield) by the reported reaction ${ }^{6}$ of $\mathrm{EGDG}^{4}$ with octyl or decyl alcohol. A dichloro- methane solution of 1 was added to the mixture of chlorosulfonic acid and glacial acetic acid ${ }^{97}$ at $0^{\circ} \mathrm{C}$ $\left[\mathrm{ClSO}_{3} \mathrm{H}: \mathrm{AcOH}: 1=10: 10: 3\right.$ (molar ratio)]. After $3 \mathrm{~h}$ of stirring at room temperature, the reaction mixture was neutralized with $2 \mathrm{~N}$ aq $\mathrm{Na}_{2} \mathrm{CO}_{3}$ and diluted with saturated aq $\mathrm{NaHCO}_{3}$. This solution was extracted with $n$ - $\mathrm{BuOH}$ several times and the evaporation of the solvent gave TLC-pure disodium disulfates (2) [Yield : 2 a (viscous liquid); $90 \%, \quad 2 \mathrm{~b} \quad\left(\mathrm{mp}: 75 \sim 82^{\circ} \mathrm{C}\right)$; $87 \%$ ]. Disodium disulfonates (3) were prepared by the reaction of propanesultone with 1 in the presence of powdered $\mathrm{NaOH}$ at $130^{\circ} \mathrm{C}[1: \mathrm{NaOH}$ : propanesultone $=3: 10: 9 \quad$ (molar ratio)]. TLC-pure products were obtained by the $n-\mathrm{BuOH}$ extraction of the reaction mixture diluted with saturated aq $\mathrm{NaHCO}_{3}$ and the subsequent evaporation of the solvent [Yield : $3 \mathbf{a} \quad(\mathrm{mp} ; 155 \sim$ $\left.\left.170^{\circ} \mathrm{C}\right) ; 25 \%, \quad 3 \mathrm{~b} \quad\left(\mathrm{mp} ; 140 \sim 155^{\circ} \mathrm{C}\right) ; 30 \%\right]$. Their structures were confirmed by ${ }^{1} \mathrm{H}$ NMR and elemental analyses.

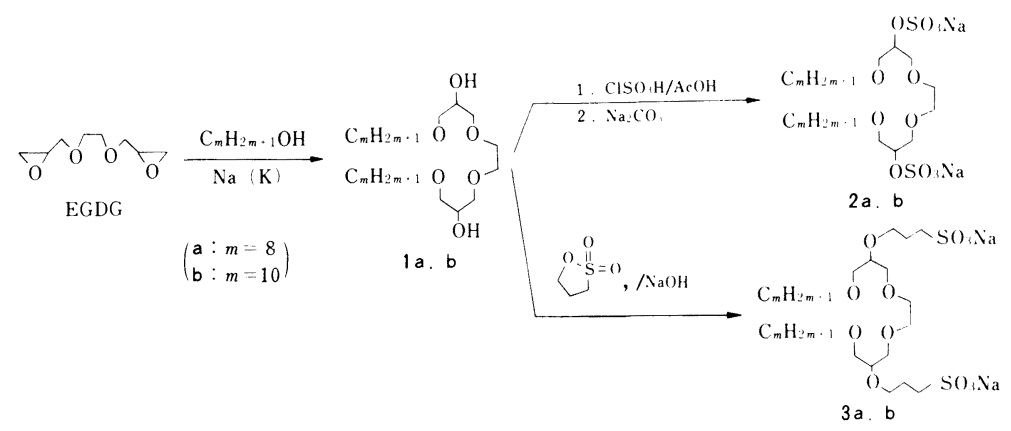

Fig. -1 Synthetic routes to amphipathic compounds $(2,3)$ with two hydrophilic ionic groups and two lipophilic alkyl chains. 
Table-1 Surface active properties of 2, 3, and typical anionics.

\begin{tabular}{|c|c|c|c|c|c|}
\hline \multirow{2}{*}{ Surfactant } & \multirow{2}{*}{$\begin{array}{l}\mathrm{T}_{\mathrm{KP}} \\
\left({ }^{\circ} \mathrm{C}\right)\end{array}$} & \multirow{2}{*}{$\begin{array}{c}10^{4} \mathrm{cmc} \\
(\mathrm{M})\end{array}$} & \multirow{2}{*}{$\begin{array}{c}\gamma_{\mathrm{cmc}} \\
\left(\mathrm{mN} \cdot \mathrm{m}^{-1}\right)\end{array}$} & \multicolumn{2}{|c|}{ Foam volume $(\mathrm{mL})$} \\
\hline & & & & $0^{\prime}$ & $60^{\prime}$ \\
\hline $2 a$ & $<0$ & 6.0 & 29.2 & 220 & 0 \\
\hline $2 \mathrm{~b}$ & $<0$ & 0.13 & 27.0 & 250 & 100 \\
\hline $3 a$ & $<0$ & 7.0 & 29.2 & 140 & 0 \\
\hline $3 \mathrm{~b}$ & $<0$ & 0.47 & 29.0 & 260 & 40 \\
\hline $\left.\mathrm{C}_{12} \mathrm{H}_{25} \mathrm{SO}_{4} \mathrm{Na}^{a}\right)$ & 16 & $82^{b)}$ & $38.5^{b)}$ & \multicolumn{2}{|c|}{-.. c) } \\
\hline $\mathrm{C}_{18} \mathrm{H}_{37} \mathrm{SO}_{4} \mathrm{Na}^{\text {a) }}$ & 56 & 2. $3^{d)}$ & $40.6^{c)}$ & \multicolumn{2}{|c|}{$\ldots$ c) } \\
\hline $\mathrm{C}_{12} \mathrm{H}_{25} \mathrm{SO}_{3} \mathrm{Na}^{\text {a) }}$ & 38 & $97^{f)}$ & $37.6^{f)}$ & \multicolumn{2}{|c|}{$\ldots$ (-. $)$} \\
\hline
\end{tabular}

a) Ref. 11. b) $\mathrm{At} 25^{\circ} \mathrm{C}$. c) Unavailable. d) $\Lambda t 50^{\circ} \mathrm{C}$. e) Ref. 12; 0.1\% turbid dispersion at $25^{\circ} \mathrm{C}$. f) At $40^{\circ} \mathrm{C}$.

The Krafft point $\left(T_{\mathrm{KP}}\right)$ of 2 and 3 was determined with a 1 wt $\%$ aqueous solution. The $\mathrm{cmc}$ and the lowering ability of surface tension $\left(\gamma_{\mathrm{cmc}}\right)$ were measured by the Wilhelmy method in water at $20^{\circ} \mathrm{C}$, and the foaming properties were evaluated by the semi-micro TK method"'1' with a 1 wt $\%$ aqueous solution of surfactants at $20^{\circ} \mathrm{C}$. Surface active properties of these compounds are listed in Table-1 with reported data of some typical alkyl sulfates and sulfonate ${ }^{11,12 !}$. Purity of samples was also ascertained from the observed sharp break in each surface tension-logarism concentration curve.

Since the $T_{\mathrm{KP}}$ values of 2 and 3 not only with two octyl groups but also with two decyl groups as the lipophilic part are below $0^{\circ} \mathrm{C}$, these compounds in this work possess good watersolubility. It was reported that branched alkyl sulfates ${ }^{21}$, sulfates with oligo(oxyethylene) group between alkyl chain and terminal sulfate groups ${ }^{122}$, and alkyl- $\alpha, \omega$-disulfates ${ }^{31}$ showed lower $T_{\mathrm{KP}}$ values than linear alkyl sulfates with the same number of carbon atoms in the alkyl group. Although compounds $(2,3)$ are new types of surfactants, a remarkable decrease of $T_{\mathrm{KP}}$ of 2 and 3 may be attributed to the co-operated effect of centrally located hydrophilic part as discussed about branched alkyl anionics" ${ }^{2}$, oxyethylene group, and two sulfate groups. Whereas the $\mathrm{cmc}$ value generally increases as the hydrophilicity of the molecule increases in a series of typical anionics ${ }^{11 \prime}$, the $\mathrm{cmc}$ values of 2 and 3 and fairly small in spite of their good hydrophilicity.

Surfactants with plural lipophilic groups generally show lower $\gamma_{\mathrm{cmc}}$ values than ones with a single lipophilic group ${ }^{13}$. The lowering ability of surface tension of 2 and 3 is exceptionally good compared with other anionic surfactants. Moreover the foaming ability of these compounds is also good, and the foam stability of $2 b$ and $3 b$ with longer alkyl chains is excellent.

To clarify the correlation between the structure and the properties of these types of compounds, an investigation of the effect of connective group between two lipophilic groups or the kind of both lipophilic and hydrophilic groups on surface active properties is now in progress.

(Received July. 4, 1988)

\section{References}

1) For example, T. Kunitake, Yukagaku, 31, 345 (1982).

2) For example, E. Götte and M. J. Schwuger, Tenside, 6, 131 (1969) ; M. J. Rosen, J. Am. Oil Chem. Soc., 49, 293 (1972).

3) For example : M. Ueno, S. Yamamoto, and K. Meguro, J. Am. Oil Chem. Soc., 51, 373 (1974); K. Meguro, K. Ikeda, A. Otsuji, M. Taya, M. Yasuda, and K. Esumi, J. Colloid Interface Sci., 118, 372 (1987).

4) X.P. Gu, I. Ikeda, and M. Okahara, Synthesis, 1985,649

5) H. Maeda, T. Kikui, Y. Nakatsuji, and M. Okahara, Synthesis, 1983, 185. 
6) Y. Nakatsuji, Y. Tsuji, I. Ikeda, and M. Okahara, J. Org. Chem., 51, 78 (1986).

7) I. Ikeda, Y. Tsuji, Y. Nakatsuji, and M. Okahara, J. Org. Chem., 51, 1128 (1986).

8) X-P. Gu, I. Ikeda, M. Okahara, and J. Kim, Chem. Lett., 1986, 1715.

9) K. Shimokai and M. Fukushima, Yukagaku, 12, 516 (1963).

10) W. Yano and W. Kimura, Yukagaku, 11, 138 (1962).

11) M.J. Rosen, "Surfactants and Interfacial Phenomena”, John Wiley \& Sons, New York (1978), p. 93, 94, 162.

12) S. Shore and D.R. Berger, “Anionic Surfactants (part I )”, ed by W. M. Linfield, Mercel Dekker, Inc., New York (1976), p. 161.

13) G. S. Hartley, Trans. Faraday Soc., 37, 130 (1941).
二つの親水性イオン基と二本の親油性アルキ ル鎖を有する新しい型の両親媒性化合物の

\section{界面活性能}

岡原光男 - 益山新樹 - 炭田康史 - 朱 云鵬 大阪大学工学部応用化学科 ( 5565 吹比闹山田丘 2-1)

エチレングリコールジグリシジルエーテルとオクチル アルコールまたはデシルアルコールの反忘により得られ る 1,8-ビス (アルキルオキシメチル)-3,6-ジオキサオク タン-1,8-ジオールを出発物質として，1,8-ビス（アルキ ルオキシメチル)-3, 6-ジオキサオクタン-1, 8-ジ（硫酸ナ トリウム) 及び 5,12 -ビス（アルキルオキシメチル）. 4, 7, 10,13-テトラオキサへキサデカン-1, 16-ジ（スルホ ン酸ナトリウム) を合成した。これらの新しい型の化合 物は，水中で優れた界面活性能を示した。 